\title{
Genetic-economic comparison of New Zealand Holstein and Jersey-New Zealand Holstein cross under a pastoral scheme in southern Chile
}

\author{
Evaluación genético-económica de Holstein Neozelandés y cruzamiento Jersey- \\ Holstein Neozelandés en un sistema pastoril de la X Región de Chile
}

J Delgadilloa , H González, H Uribe ${ }^{b *}$

\begin{abstract}
Chilean bovine dairy production needs to increase milk solid content. This study evaluates and compares genetic and economic progress of New Zealand Holstein (HoNZ) and New Zealand Jersey-HoNz crossbreed (Fx) using selection indices. The traits analysed were: milk (L) with $3 \%$ fat and 3\% protein (LB), fat (kg) over 3\% in LB (PF), protein (kg) over 3\% in LB (PP) and body weight (BW). A multivariate mixed model was used for genetic parameters estimation using AIREMLF90 software. Economic values were estimated using costs associated with dry matter (DM) intake required to supply energy requirements of each trait and income as defined by PROLESUR payment to producer scheme for LB, PF and PP. Genetic progress of PF, PP and BW were similar for the two studied genotypes, but LB progress was higher in HoNz. Economic progress was similar between genotypes, but the offspring of Fx achieves a greater economic benefit per animal and per surface of land, due to higher production of PF and PP. Genetic improvement of Fx using a selection index, allows to achieve higher average of solids production and higher economic benefit.

Keywords: genetic improvement, milk, solids.
\end{abstract}

RESUMEN. La producción de leche bovina requiere incrementar el contenido de sólidos. Este estudio evaluó y comparó el progreso genético y económico del Holstein Neozelandés (HoNz) y del cruzamiento Jersey Neozelandés-HoNz (Fx) utilizando índices de selección. Las características analizadas fueron: leche (L) con 3\% de grasa y 3\% de proteína (LB), grasa (kg) sobre 3\% en LB $(\mathrm{PF})$, proteína $(\mathrm{kg})$ sobre $3 \%$ en LB (PP) y peso vivo (BW). Se utilizó un modelo mixto multivariado para realizar estimaciones de parámetros genéticos usando AIREMLF90. Se estimaron valores económicos usando los costos asociados al consumo de materia seca necesario para suplir los requerimientos de energía de cada característica y los ingresos de la pauta de pago de PROLESUR para LB, PF y PP. El progreso genético de PF, PP y BW fue similar entre los biotipos, pero el de LB fue mayor en HoNz. El progreso económico fue similar entre los biotipos, pero la descendencia de Fx permite conseguir un mayor retorno económico por animal y por superficie gracias a su mayor producción de PF y PP. El mejoramiento genético de Fx utilizando índices de selección permite conseguir mayores promedios de producción de sólidos y un mayor beneficio económico para el plantel.

Palabras clave: mejoramiento genético, leche, sólidos.

\section{INTRODUCTION}

Seventy percent of industrialised milk in Chile is produced in the southern part of the country, and the most important production areas are Araucanía (IX), Los Lagos (X) and Los Ríos (XIV) (Lerdón et al 2010) where milk production is mainly based on grazing pastures where the goal is to obtain high production per unit of land (González-Verdugo et al 2004).

The main factors influencing economic return are: 1) liters (L) of milk containing $3 \%$ weight/volume (w/v) of milk fat plus $3 \% \mathrm{w} / \mathrm{v}$ of protein, which is known as standardized liter of milk (LB); 2) kilograms ( $\mathrm{kg}$ ) of fat above $3 \% \mathrm{w} / \mathrm{v}$ in each $\mathrm{L}$ of $\mathrm{LB}(\mathrm{PF})$ and, 3 ) $\mathrm{kg}$ of protein above $3 \% \mathrm{w} / \mathrm{v}$ in each $\mathrm{L}$ of LB (PP). The payment scheme of the industry for raw milk is influenced by these three

Accepted: 24.03.2016.

aTexas A\&M University, College Station, TX, USA.

bepartamento de Producción Animal, Facultad de Ciencias Agronómicas, Universidad de Chile, Santiago, Chile.

*Corresponding author: H Uribe; hector.a.uribe@gmail.com factors (PROLESUR) ${ }^{1}$. On the other hand, body weight (BW) also represents an important factor to be accounted for in this type of pastoral milk production, because as BW per cow decreases, more cows can be carried per unit of land. Lighter cows have lower nutritional requirements compared with heavier cows (Hazard 2004).

As part of its "Strategies for Competitive Development of the Chilean Dairy Sector 2010-2020" document, the Milk Consortium S. A. ${ }^{2}$ outlined a production blueprint to be followed by the dairy sector. In relation to the improvements of economically important traits, it was pointed out that there is the need to move toward dairy breeds whose milk has higher milk solids (fat and protein) concentrations. The goal, as indicated by the Consortium,

Prolesur. 2014. Resumen de Pauta de Pago de leche para la compra que PROLESUR realiza a los actuales productores de leche de la X Región de Los Lagos, Continental. Vigencia: Desde el 1 de septiembre de 2014. www.prolesur.cl/component/docman/ doc_download/249-pauta-de-precios-leche-cruda-X-continentalsept-14; accessed July 28, 2013.

2 Consorcio Lechero, 2010. Estrategia de desarrollo competitivo del sector lácteo chileno, 2010-2020. www.consorciolechero.cl/chile/ docs/Estrategia-Desarrollo-Sectorial-2010-2020.pdf; accessed April 10, 2013. 
is to a reach national milk solids concentration of $7.6 \%$ in 2020 compared with the current $7.1 \%$ in 2010.

Improvement of the economically important traits can be reached by two ways; firstly, through farm management practices, such as improvement in animal nutrition and health. Change in management practices leads to immediate improvements however, are temporal and may sometimes lead to increased production costs. The second way to increase milk solids concentrations is through genetic improvement, which in the medium and long term, leads to cumulative and permanent changes (Conington et al 2001).

Selection indexes maximize economic profit by selecting breeding stock not only based on genetic merit; but also include the candidate's overall economic merit (Hazel 1943). A selection index represents an estimation of the selection objective or aggregate genotype, which is the true genetic-economic value of an animal obtained as the sum of the economic contribution of each trait included in the index. Therefore, knowledge on the economic value of each trait is needed to develop an estimation of the index value, with the economic value being defined as the additional net return obtained by increasing the output by one unit of the trait keeping the other traits unchanged (Cameron 1997).

In Chile, there are studies concerning the selection indexes for productive domestic animals, among them, dual purpose and meat sheep (Lembeye et al 2014), Corriedale sheep (Barría et al 1998) and Hereford cattle (Amthauer 1995); however, in spite of the advantages of genetic improvement using selection indexes and the economic importance of pastoral dairy production in southern Chile, there is no Chilean information regarding the use of selection indexes in pastoral dairy cattle.

Among dairy breeds and crossbreds suitable for pastoral systems, the New Zealand Holstein (HoNz) and the New Zealand Jersey-HoNz (Fx) cross are found in Chile; these genotypes are under the dairy genetic improvement program in New Zealand, which is focused on increasing milk solids content (López-Villalobos et al 2000, Livestock Improvement 2004, López-Villalobos and Garrick 2005, Sneddon 2011).

Due to some similarities between production objectives in dairy pastoral systems of New Zealand and Chile, $\mathrm{HoNz}$ genotype is one of the breeds that forms the dairy herd of southern Chile; however in the scientific literature reviewed here, there are no Chilean studies aimed at determining which breed or crossbred provides the greatest economic progress based on increasing milk solids output per unit of land.

The development of selection indexes, specifically for HoNz and Fx which considers milk, milk solids and $\mathrm{BW}$, would provide information about which is the most suitable genotype for economic returns under southern Chilean pastoral conditions.

The objective of this study was to determine, under the current Chilean milk production economic scenario, which genotype would yield greater genetic and economic progress by jointly selecting for lower BW and higher LB, $\mathrm{PF}$ and PP production, using selection indexes.

\section{MATERIAL AND METHODS}

DATA

Between 2001 and 2011 data were gathered at Oromo Research Station, a farm owned by the Faculty of Agricultural Sciences of the Universidad de Chile and located in Purranque, Lake District, Chile ( $\left.41^{\circ} 08 \mathrm{~S}, 73^{\circ} 09 \mathrm{~W}\right)$.

The records from 317 and $128 \mathrm{HoNz}$ and Fx cows, respectively, were considered for the study, HoNz cows had a genetic makeup of at least $75 \% \mathrm{HoNz}$; Fx genotype were crossbred cows obtained using New Zealand Jersey semen on HoNz cows, Jersey genes fluctuated between 25 to $75 \%$. The final data set contained 823 and 440 lactations for HoNz and Fx, respectively.

Besides genotype, the variables used in this study were cow identification, sire and dam identification, month and year of calving parturition number (NOP), days in milk, BW and lactation yield $(\mathrm{kg})$ of milk, fat and protein.

The pasture at Oromo Research station has a clearly marked productive seasonality; the growth reaches its maximum in the first and second week of October, peaking up to $70 \mathrm{~kg}$ dry matter (DM)/day. In Summer, both productivity and nutritional quality decrease. Minimal growth occurs in winter time. The average botanical composition of the pasture is: Lolium perenne (70\%); Dactilis glomerata (15\%), Anthoxanthum odoratum, Bromus sp., Trifolium repens y Achillea mellefolium (5\%) and other species (10\%). Grazing is rotational, keeping a stocking rate of 2.45 cows/ha/year. During the non-lactating period (May and June) the cows are fed silage ad libitum. Two to three weeks before calving the cows are moved to calving paddocks where, along with silage, they are supplemented with concentrate without exceeding to $2 \mathrm{~kg} / \mathrm{cow} /$ day. After calving, cows are fed with silage and the amount of concentrate is doubled to $4 \mathrm{~kg} / \mathrm{day}$. The amounts of silage offered begins to decrease as spring pasture growth replaces it; concentrate supplementation also decreases until pasture completely replaces silage and concentrate in the third week of September. Consequently the calving date of the cow determines the amount of concentrate given at the beginning of lactation. Mineral supplementation is provided around the year according to physiological condition and production level. To ensure that mineral supplementation is consumed by the cows it is mixed with the silage and, when silage is not offered, it is offered at the milking parlour. The goal of reproductive management is to concentrate calving toward the end of winter to match the largest nutritional requirement of the herd with the highest pasture growth.

Lactations began between July and November in each year. Parturition number ranged between 1 and 11 however, 
due to both genotypes having fewer records beyond parturition 6; records from NOP 7 to 11 were grouped in a single category. A single BW record per lactation was recorded on each cow a day after calving. Lactations had a minimum of 200 days in milk and those exceeding 305 days in milk were shortened to the nearest 305 days record.

Traits with economic relevance were: 1) L of standardised milk containing 3\% w/v of fat and 3\% w/v of protein (LB), this was calculated as follows: $\mathrm{LB}=\frac{\mathrm{LA}}{\mathrm{DC}}$, where, LA is total milk yield per lactation $(\mathrm{kg})$ and $\mathrm{DC}$ is the milk density coefficient (1.03; FAO, 2012); 2) kg of fat above $3 \% \mathrm{w} / \mathrm{v}$ in each L of LB (PF), this was defined as: $\mathrm{PF}=\mathrm{FAT}-(0.03 * \mathrm{LB})$, where FAT is total $\mathrm{kg}$ of fat yield per lactation; and 3 ) $\mathrm{kg}$ of protein above $3 \% \mathrm{w} / \mathrm{v}$, this was defined as: $\mathrm{PP}=\mathrm{PROT}-(0.03 * \mathrm{LB})$, where PROT is total $\mathrm{kg}$ of protein yield per lactation.

\section{ESTIMATES}

Least squares means (LSM) of BW were estimated to assess economic values of the selection index. Furthermore, LSM for BW, LB, PF and PP were used to assess population changes after one generation of selection using the indexes derived for both genotypes. This was done to estimate the expected cow performance, which a dairy producer would achieve, in the medium term, using this methodology, under environmental and management conditions similar to those of Oromo research farm.

Additive genetic values were estimated using a multivariate linear mixed model, in order to be used in the selection indexes. The BW model considered the fixed effect of genotype, month and year of calving, NOP, and the random effects of animal $\sim \mathrm{N}\left(0, \mathrm{~A} \sigma_{\mathrm{a}}^{2}\right)$ and permanent environment. For LB, PF, and PP the model included the same aforementioned variables plus fixed effect of days in milk as a covariate. The model also included relationship information among animals, and was solved using BLUP methodology by the AIREMLF90 software (Misztal et al 2002).

Aggregate genotype or total genetic merit function for each animal $(\hat{H})$ was estimated as follows: $\hat{H}=v_{1} \hat{A}_{1}+v_{2} \hat{A}_{2}+v_{3} \hat{A}_{3}+v_{4} \hat{A}_{4}$, where $v_{\mathrm{i}}$ is the economic value of the $\mathrm{i}^{\text {th }}$ trait in the index, $\mathrm{i}=\mathrm{LB}, \mathrm{PF}, \mathrm{PP}$ and $\mathrm{BW}$. $\hat{\mathrm{A}}_{i}$ is the estimated breeding value of a given animal for the $\mathrm{i}^{\text {th }}$ trait.

Economic value estimation. Economic value was defined as the difference between income and cost associated to increase a single unit of each trait included in the selection index.

Additional income from the production of a $\mathrm{L}$ of $\mathrm{LB}$, a $\mathrm{kg}$ of $\mathrm{PF}$ and a $\mathrm{kg}$ of PP were obtained from the current raw milk payment scheme of the PROLESUR company. Therefore, income was 119,1,200 and 5,800 Chilean pesos for each $\mathrm{L}$ of $\mathrm{LB}, \mathrm{kg}$ of $\mathrm{PF}$ and $\mathrm{kg}$ of PP, respectively. Additional income for a $\mathrm{kg}$ of $\mathrm{BW}$ was set to zero due to the fact that incremental changes in BW do not imply direct economic benefits.

To standardise costs, consumption of DM necessary to supply the metabolizable energy (ME) requirement associated with an incremental change in a unit of each trait, was used (Daza 1997, Chamberlain and Wilkinson 2002).

As diet composition varies within a given lactation, an average lactation feed composition was estimated based on the percentage of DM consumption of each diet ingredient. The ingredients were pasture, grass silage and concentrate. Total consumption per lactation was the sum of DM consumption from the three ingredients aforementioned.

Lactation pasture consumption. This was calculated using the following equation: $\mathrm{CP}=\mathrm{CPT}-\mathrm{CC}-\mathrm{CE}-(\mathrm{TS} * \mathrm{CC})$, where $\mathrm{CP}$ is lactation pasture consumption ( $\mathrm{kg}$ of $\mathrm{DM})$, CPT is the lactation potential consumption ( $\mathrm{kg}$ of DM), $\mathrm{CC}$ is lactation concentrate consumption ( $\mathrm{kg}$ of $\mathrm{DM})$, $\mathrm{CE}$ is lactation silage consumption ( $\mathrm{kg}$ of DM), TS is the pasture by concentrate substitution rate which, for this study, was defined as 0.4 . The chosen TS value is within the range from 0.26 to 0.55 described for Holstein cows under low and high pasture allowance, respectively (Bargo et al 2002). To estimate CPT it was considered that DM consumption differences existed within lactation, therefore, a weighted average consumption was calculated according to stage of lactation. Consumption was calculated as a percentage of BW based on the assumption that within lactation, there are DM consumption differences as follows (Hazard 2004), a) DM consumption in the initial third of lactation $=3.5 \%$ of $\mathrm{BW}, \mathrm{b}$ ) DM consumption in the middle part of lactation $=3.0 \%$ of BW, c) DM consumption in the last third of lactation $=2.5 \%$ of $\mathrm{BW}$.

Average body weight in each third of lactation. To account for the fact that $\mathrm{BW}$ varies within lactation, a simulation was used to model BW changes in each lactation third, the assumptions used were (Hazard 2004), a) from the first to second month of lactation BW decreases by $1 \mathrm{~kg}$ per day, b) from the third to fifth month of lactation there is no change in $\mathrm{BW}, \mathrm{c}$ ) from the sixth to the tenth month of lactation BW gradually increases until the beginning of dry period, reaching the same BW as it was previous to calving. LSM for BW in both genotypes were used as starting values for the simulation; then average BW of each lactation third, for both genotypes, were calculated to estimate potential consumption.

Lactation concentrate consumption. Concentrate supplementation scheme at Oromo Research Station, by default, consists of offering $4 \mathrm{~kg}$ of concentrate per day, from July 15 to September 20. Therefore, a consumption weighted average was calculated per lactation using records of cows that calved within the above mentioned period. Dry matter consumption was estimated from concentrate 
consumption, assuming concentrate had a DM of $88 \%$ (Anrique et al 2014).

Lactation silage consumption. Silage supplementation at Oromo Research Station is routinely practiced with cows calving between July 15 and September 7. Furthermore, silage supplementation changes overtime; each cow is offered 8, 5 and $3 \mathrm{~kg}$ in July, August and September, respectively. From this, average kg of silage consumption, per cow, was calculated according to calving date and, DM consumption was estimated assuming that silage has 42\% DM (Anrique et al 2014).

Feed metabolizable energy. Estimation of metabolizable energy (ME) content per kg of feed DM was calculated based on the energetic information and consumption percentage of each feed ingredient, the following equation was used: $\mathrm{EMA}=(\mathrm{EMC} * \% \mathrm{C})+(\mathrm{EME} * \% \mathrm{E})+(\mathrm{EMP} * \% \mathrm{P})$, where EMA is mega calories (Mcal) of ME per $\mathrm{kg}$ of DM of the lactation average diet, EMC is Mcal of ME per $\mathrm{kg}$ of DM from concentrate feed, EME is Mcal of ME per $\mathrm{kg}$ of DM from silage, EMP is Mcal of ME per kg of DM from pasture, $\% \mathrm{C}, \% \mathrm{E}$ and $\% \mathrm{P}$ are consumption percentages of concentrate, grass silage and pasture, respectively.

Concentrate and grass silage energy. Information regarding energetic content per $\mathrm{kg}$ of DM in concentrate and silage was obtained from dairy cow supplement nutrient tables; which were specifically designed for grazing dairy cows (Parga and Lanuza 2006). Energy content used was 2.8 Mcal of ME per $\mathrm{kg}$ of DM for concentrate (oat grain) and 2.5 Mcal of ME per kg of grass silage.

Pasture energy. ME per kg of DM in pasture varies over time, therefore an ME weighted average was used which was based on nutritional information provided by the Institute for Agricultural Research (INIA) for permanent pastures, such as those found at Oromo Research Station (Parga and Lanuza 2006). According to INIA, winter pasture contains 2.7 Mcal of ME per kg of DM, spring pasture contains 2.9 Mcal of ME per kg of DM, summer pasture contains 2.4 Mcal of ME per $\mathrm{kg}$ of DM and autumn pasture contains 2.7 Mcal of ME per $\mathrm{kg}$ of DM.

Ingredient consumption percentage of each genotype. DM consumption of each genotype was calculated as follows: $\%$ Cons. $I_{i}=\frac{\text { Cons. } I_{i}}{\text { Cons. } T} * 100$,

where Cons. $I_{t}$ is DM consumption of the $\mathrm{i}^{\text {th. }}$ feed ingredient ( $\mathrm{i}=$ pasture, silage, concentrate) of each genotype, and Cons.T is total DM consumption of each genotype.

Additional DM consumption and requirement, per output unit, of each trait according to genotype. Estimation of DM consumption, for FX and HoNz, was calculated based on the relationship between $\mathrm{ME}$ requirements, associated with an additional unit of LB, PF, PP and BW, and ME content of DM in the average feed diet.

$M E$ requirements to produce and additional unit of $L B$, $P F$ and PP. Requirements, in Mcal of ME per L of LB were calculated using the following formula:

$$
M E_{\text {Mcal }} / L B_{1 L}=\frac{0.24 * d *(0.95+(0.04 * 30)+(0.02 * 30))}{k l},
$$

where $d$ is milk density (1.03) and $k l$ is ME utilization efficiency expressed as net energy for lactation (EN1). In this study the $k l$ value used was 0.64 (González-Verdugo et al 2004).

For one $\mathrm{kg}$ of $\mathrm{PF}$ the formula was:

$$
M E_{\text {Mcal }} / P F_{1 k g}=\frac{0.24 * d *(0.95+(0.04 * 1030)+(0.02 * 30))}{k l}-M E_{M c a l} / L B_{1 L} \text {. }
$$

The additional requirement to produce an additional $\mathrm{kg}$ of PP was:

$$
M E_{\text {Mcal }} / P P_{1 k g}=\frac{0.24 * d *(0.95+(0.04 * 30)+(0.02 * 1030))}{k l}-M E_{M c a l} / L B_{1 L} .
$$

$\mathrm{ME}$ requirement to maintain an additional $\mathrm{kg}$ of $\mathrm{BW}$

$$
M E_{\text {Mcal }} / B W_{1 k g}=(0.24 *(17.2+(0.07 *(1+1))))-(0.24 *(17.2+(0.07 * 1))
$$

DM Consumption to produce an additional unit of LB, $\mathrm{PF}$ and PP.

DM necessary to produce an additional L of LB was:

$$
D M_{K g} / L B_{L}=\frac{M E_{M c a l} / L B_{1 L}}{E M A},
$$

for an additional $\mathrm{kg}$ of PF was

$$
D M_{K g} / P F_{1 k g}=\frac{M E_{M c a l} / P F_{1 k g}}{E M A} \text {, }
$$

and for each additional $\mathrm{kg}$ of PP was:

$$
D M_{K g} / P P_{1 k g}=\frac{M E_{M c a l} / P P_{1 k g}}{E M A} \text {. }
$$

DM Consumption to maintain an additional $\mathrm{kg}$ of BW was: $D M_{K g} / B W_{1 k g}=\frac{M E_{M c a l} / K g_{B W}}{E M A}$.

Additional cost of a $\mathrm{kg}$ of DM in each diet ingredient

To estimate additional DM intake costs for each genotype, the DM requirement associated with an incremental change in the output unit of each trait was multiplied by the cost of a $\mathrm{kg}$ of DM of each feed ingredient.

Cost of a $\mathrm{kg}$ of DM of the diet. The cost of a $\mathrm{kg}$ of DM of the diet $\left(\$ D M_{k g F e e d}\right)$ was calculated as follows:

$$
\begin{aligned}
& \$ D M_{K g \text { Feed }}=\left(\$ D M_{K g \text { Conc }} * \% \text { Concentrate }\right)+ \\
& \left(\$ D M_{K g \text { Sil }} * \% \text { Silage }\right)+\left(\$ D M_{K g \text { Past }} * \% \text { Pasture }\right)
\end{aligned}
$$

where: $\$ D M_{k g C o n c}$ is the price of a $\mathrm{kg}$ of $\mathrm{DM}$ from concentrate.

$\$ D M_{k g S i l}$ is the price of a $\mathrm{kg}$ of DM from grass silage. $\$ D M_{k g \text { Past }}$ is the price of a $\mathrm{kg}$ of DM from pasture, being this last one defined as:

$$
\$ D M_{K g \text { Past }}=\left(\frac{C M}{P R P}\right) *(\% \text { Ofer })^{-1} *(\% \text { Cons })^{-1} \text {, }
$$

where $\mathrm{CM}$ are the costs associated with pasture maintenance plus 6\% unforeseen costs (Teuber 2009), PRP is 
the $\mathrm{kg}$ of DM/ha grown each year, which, was assumed to be $10,000 \mathrm{~kg} \mathrm{DM} /$ ha per year (Teuber 2009). \%Ofer is pasture percentage available for consumption leaving $25 \%$ for pasture regrow, and \%Cons is the offered percentage of the pasture which is effectively consumed by the cow. According to historical production records of Oromo Research Farm \%Cons was assumed to be $75 \%$.

Costs associated to the additional output of $1 \mathrm{~L}$ of $L B$ $(\$ L B), 1 \mathrm{~kg}$ of $P F\left(\$ F_{1 k g}\right), 1 \mathrm{~kg}$ of $P P\left(\$ P_{1 k g}\right)$ and maintenance of one additional $k g$ of $B W\left(\$ B W_{1 k g}\right)$.

The cost for LB was: $\$ L B=D M_{K g} / L B_{L} * \$ D M_{K g \text { Feed }}$.

The cost of PF was: $\$ F_{1 k g}=D M_{K g} / F_{1 k g} * \$ D M_{K g \text { Feed }}$.

The cost of PP was: $\$ P_{1 k g}=D M_{K g} / P_{1 k g} * \$ D M_{K g}$ Feed .

ThecostofBWwas: $\$ B W_{1 k g}=D M_{K g} / 1 K g_{B W} * \$ D M_{K g \text { Feed }}$.

Genetic-economic progress selecting using a selection index. A $t$ test, modified by Welch (Welch 1938), was used to compare selection index average values between both genotypes.

\section{RESULTS}

Least square means and their standard errors for both genotypes are presented in table 1. Milk solid yield for the Fx was greater than the HoNz however, milk yield was greater for the HoNz.

\section{DRY MATTER CONSUMPTION}

After simulation of BW across lactation for both genotypes, potential DM consumption was estimated. Consequently Fx had a potential consumption of $3,819 \mathrm{~kg}$ of DM per lactation (12.5 kg DM daily average). Potential consumption for HoNz was estimated in 4,150 kg of DM per lactation (13.6 kg DM daily average).

Feed ingredients ME was estimated at 2.80, 2.50 and $2.67 \mathrm{Mcal}$ of ME per kg of DM for concentrate, silage and pasture, respectively; using this, consumption percentage and energy intake was estimated as shown in table 2.

\section{REQUIREMENT AND CONSUMPTION OF METABOLIZABLE ENERGY PER UNIT OF EACH TRAIT}

The estimated metabolisable energy required to increase one unit of LB, PF, PP and BW was 1.04, 14.45, 8.03 and $0.02 \mathrm{Mcal}$, respectively. The result is consistent with the expectations, because the high energy concentrated in one $\mathrm{kg}$ of PF and PP demands a higher ME than the ME needed to produce one extra liter of LB, and to satisfy the maintenance requirements of an extra $\mathrm{kg}$ of BW. As a consequence, additional DM consumption associated to a unit of LB, PF, PP and BW was 0.39, 5.41, 3.01 and $0.01 \mathrm{~kg}$, respectively.

According to current Chilean feedstock market prices the estimated cost of a $\mathrm{kg}$ of DM from each feed ingredient was 227,48 and 43 Chilean pesos (\$) for concentrate, silage and pasture, respectively.

Using the previous information, the resulting economic values needed to build the selection index, are shown in table 3 for both genotypes.

With the economic values presented in table 3 the aggregate genotype estimations for Fx and HoNz were:

$$
\begin{aligned}
& \hat{H}_{F x}=(99.47) \hat{A}_{1}+(930.09) \hat{A}_{2}+(5649.97) \hat{A}_{3}-(0.33) \hat{A}_{4} \\
& \text { and, } \\
& \hat{H}_{H o N z}=(99.68) \hat{A}_{1}+(933.11) \hat{A}_{2}+(5651.65) \hat{A}_{3}-(0.33) \hat{A}_{4}, \\
& \text { respectively; }
\end{aligned}
$$

where $\hat{A}_{i j}$ is the estimated additive genetic value for the $\mathrm{i}^{\text {th }}$ trait of the $\mathrm{j}^{\text {th }}$ animal. Aggregate genotypes were estimated for all animals within breed and averages of Fx and HoNz were compared. Average aggregate genotype for Fx was $4,047.53$ Chilean pesos which is significantly greater than the HoNz, whose aggregate genotype was -2,248.81.

\section{DISCUSSION}

To estimate the economic values for the traits included in the selection indexes, it was necessary to develop a

Table 1. Least square means of $\mathrm{LB}^{1}, \mathrm{PF}^{2}, \mathrm{PP}^{3}$ and $\mathrm{BW}^{4}$ according to genotype. Medio mínimo cuadrado (LSM) de $\mathrm{LB}^{1}, \mathrm{PF}^{2}, \mathrm{PP}^{3}$ y $\mathrm{BW}^{4}$ según genotipo.

\begin{tabular}{lcccccc}
\hline \multirow{2}{*}{ Trait } & \multicolumn{3}{c}{$\mathrm{Fx}^{5}$} & & \multicolumn{3}{c}{$\mathrm{HoNz}^{6}$} \\
\cline { 2 - 3 } \cline { 6 - 8 } & LSM & $* * * * * *$ & & LSM & SE & $* * * * * *$ \\
\hline LB (L) & 5,016 & 52.0 & & 5,135 & 42.6 & 119.7 \\
PF (kg) & 93.4 & 1.9 & & 84.4 & 1.5 & 9.0 \\
PP (kg) & 33.1 & .79 & & 28.7 & 0.6 & 4.4 \\
BW (kg) & 453 & 4.4 & & 488.5 & 3.5 & 35.7 \\
\hline
\end{tabular}

$\underline{1}$ milk containing $3 \%$ weight/volume $(\mathrm{w} / \mathrm{v})$ of milk fat plus $3 \% \mathrm{w} / \mathrm{v}$ of protein; $\underline{2}-\mathrm{kg}$ of fat above $3 \% \mathrm{w} / \mathrm{v}$ in each L of LB; $\underline{\underline{3}} / \mathrm{kg}$ of protein above $3 \% \mathrm{w} / \mathrm{v}$ in each L of LB;

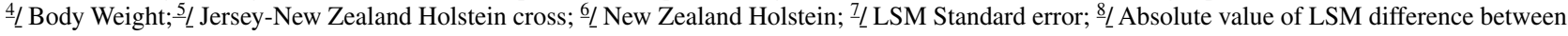
genotypes. 
Table 2. Metabolizable energy (ME) intake per kg of average feed dry mater (DM) consumption for each genotype. Consumo de energía metabolizable por kg de materia seca de alimento promedio consumido por cada genotipo.

\begin{tabular}{|c|c|c|c|c|c|}
\hline \multirow{2}{*}{ Feed Ingredient } & \multicolumn{2}{|c|}{ Consumption \% } & \multirow{2}{*}{$\begin{array}{c}\mathrm{ME} \\
\text { (Mcal/kg of DM) }\end{array}$} & \multicolumn{2}{|c|}{ Consumed ME } \\
\hline & $\mathrm{Fx}^{1}$ & $\mathrm{HoNz}^{2}$ & & Fx & $\mathrm{HoNz}$ \\
\hline Concentrate & 3.7 & 3.4 & 2.8 & 0.10 & 0.10 \\
\hline Grass Silage & 1.7 & 1.5 & 2.5 & 0.04 & 0.04 \\
\hline Pasture & 94.7 & 95.1 & 2.7 & 2.53 & 2.54 \\
\hline Total & & & & 2.67 & 2.67 \\
\hline
\end{tabular}

1] Jersey-New Zealand Holstein cross; [2] New Zealand Holstein

Table 3. Economic values of $\mathrm{LB}, \mathrm{PF}, \mathrm{PP}$ and BW according to genotype. Valores económicos de LB, PF, PP y BW según genotipo.

\begin{tabular}{lcccc}
\hline \multirow{2}{*}{ Genotype } & \multicolumn{4}{c}{ Economic Value $(\mathrm{CL} \$)^{5}$} \\
\cline { 2 - 5 } & LB & PF & PP & BW \\
\hline Fx & 99.47 & 930.09 & 5,650 & -0.33 \\
HoNz & 99.68 & 933.11 & 5,652 & -0.33 \\
\hline
\end{tabular}

$\underline{1}$ milk containing $3 \%$ weight/volume $(\mathrm{w} / \mathrm{v})$ of milk fat plus $3 \% \mathrm{w} / \mathrm{v}$ of protein; $\underline{2} / \mathrm{kg}$ of fat above $3 \% \mathrm{w} / \mathrm{v}$ in each L of LB; $\underline{3} / \mathrm{kg}$ of protein above $3 \%$ w/v in each L of LB; $\underline{4}$ / Body Weight; $\underline{5}$ / Chilean pesos

system to standardise the cost associated with each trait. Feeding is assumed to be the most important production cost (Hazard 2004, Parga and Lanuza 2006), therefore, additional DM consumption costs to produce a unit of a given trait were used. Also, changes in BW during lactation for both genotypes were simulated by using BW LSM estimates, allowing the inclusion of the variables affecting the amount and type of consumed feed to obtain results that are a close approximation to the complexity of the system (Hazard 2004).

The results show that LSM of LB, PF, PP and BW were significantly different between genotypes (table 1). For productive traits (LB, PF and PP) HoNz showed higher average LB, exceeding the Fx average by approximately 119.7 L LB. However, despite the lower Fx average for LB, the FX had a significantly greater average for PF and $\mathrm{PP}$, these being traits of economic importance for dairy producers according to the current payment scheme of the raw milk buying company (PROLESUR). These findings are similar to those indicated by other authors when comparing the same breeds (González-Verdugo et al 2004, Prendiville et al 2009).

Fx had a lower average BW than HoNz (table 1), this is in agreement with the findings of González-Verdugo et al (2004) and Prendiville et al (2009). This lower BW means that maintenance ME requirement and, in turn, DM consumption of Fx is lower, therefore the number of cows that can be kept per unit area of pasture is higher compared with HoNz. These results indicate that Fx would be better adapted to pastoral productive system, maximizing economic return per unit of grazing land. Since dairy production in southern Chile is mainly pastoral-based, economic returns of the dairy enterprise could be optimised by using Fx or similar genotype.

As part of the selection index design process, a difference in pasture consumption between genotypes was found. This can be explained due to differences in potential consumption of the two genotypes and due to the supplementation strategy of the herd, where all cows were offered, on average, the same amount of concentrate and grass silage per lactation. However, the lower potential DM consumption of Fx indicates that the feed fraction corresponding to pasture be lower than that of the HoNz. In spite of these differences, when matching the energy content of the feed ingredients to consumption percentage, it was calculated that consumed ME per kg of feed is identical in both genotypes (table 2).

Metabolizabe energy required by cows for an incremental change in a unit of each trait was as expected, that is, productive traits had a greater energetic demand than an additional $\mathrm{kg}$ of $\mathrm{BW}$; this can be explained as a consequence of the metabolic process associated and energy concentration per unit of LB, PF and PP (Nelson and Cox 2005). As ME requirements were greater for incremental changes in productive traits, DM consumption was also increased, mainly for changes in PF.

After the cost of an average $\mathrm{kg}$ of DM of feed intake was estimated, an estimation of the feeding costs for both genotypes was calculated. The Fx had a greater feeding cost per $\mathrm{kg}$ of DM in comparison with $\mathrm{HoNz}$, due to the inclusion of a lower percentage of pasture in the average $\mathrm{kg}$ of DM of feed consumed during lactation. In spite of the fact that both genotypes were fed using the same concentrate and 
silage supplementation protocol, the lower percentage of pasture in the Fx's average lactation diet, caused the relative percentage of the more expensive ingredients (silage and concentrate) to be higher in the diet. As a consequence, the cost of the estimated average $\mathrm{kg}$ of feed eaten by Fx across the lactation was greater than HoNz.

By knowing feed cost and additional DM consumption it was possible to estimate and standardize additional cost that the herd would have due to increasing a unit of each trait. With this result, and the additional income associated to increasing a unit of each trait, it was possible to estimate economic values of LB, PF, PP and BW for both genotypes (table 3). The economic values of LB, PF, and PP for the FX were lower than those for $\mathrm{HoNz}$, as a result of higher feeding costs involved to produce a unit of these traits. For BW both genotypes had the same economic value, and the selection index weighted negatively this trait when the cow estimated breeding value was above zero.

Using the aforementioned results plus economic values, aggregated genotypes for HoNz and Fx were estimated and compared; Fx had a significantly greater genetic-economic superiority of \$6,296 compared with HoNz.

In these findings one should consider that part of Fx better performance must be due to heterosis effects (LópezVillalobos et al 2000); therefore, within the selection strategy of this genotype a rotational crossing scheme, aimed to keep Fx heterozygosity, must be considered.

Finally, of the two genotypes used in this study, Fx was the best genetic-economic alternative for this farm. A significant portion of this better economic result can be explained due to the fact that Fx had a greater milk solids yield than $\mathrm{HoNz}$; and this is a direct consequence of Jersey breed genes involved in the cross. These findings indicate that Chilean dairy farmers would, in term of profitability, benefit by preferring Fx cross over $\mathrm{HoNz}$ breed. If dairy farmers want to increase milk solid output and hence profitability, the recommendation would be the use a rotational crossbreeding scheme. Construction of a selection index in a breeding program, which uses local economic parameters, is crucial in a breeding program to move the herd toward a production profit goal.

\section{REFERENCES}

Amthauer JL. 1995. Índices de selección para reproductores Hereford bajo las condiciones de la zona sur de Chile. Biblioteca Central INIA, Santiago, Chile.

Anrique R, X Molina, M Alfaro, R Saldaña. 2014. Composición de alimentos para el ganado bovino. $4^{\mathrm{a}}$ ed. Consorcio Lechero, Universidad Austral de Chile e Instituto de Investigaciones Agropecuarias Remehue, Valdivia, Chile.

Bargo F, LD Muller, JE Delahoy, TW Cassidy. 2002. Milk response to concentrate supplementation of high producing dairy cows grazing at two pasture allowances. J Dairy Sci 85, 1777-1792.
Barría N, H Montaldo, A Jara, V Martínez. 1998. Selection Index construction for the Corriedale breed in Magallanes. Proceedings $6^{\text {th }}$ World Congress on Genetics Applied to Livestock Production $24,39-42$.

Cameron ND. 1997. Selection index methodology. In: Cameron ND (ed). Selection indices and prediction of genetic merit in animal breeding. CAB International, Oxford, UK, Pp 58-67.

Chamberlain AT, JM Wilkinson. 2002. Alimentación de la vaca lechera. Acribia, Zaragoza, España.

Conington J, SC Bishop, B Groudy, A Waterhouse, G Simm. 2001. Multi-trait selection indexes for sustainable UK hill sheep production. J Ani Sci 73, 413-423.

Daza A. 1997. Reproducción y Sistemas de Explotación del ganado ovino. Mundi Prensa, Madrid, España.

González-Verdugo H, JC Magofke, C Mella. 2004. Productivity, intake and biological efficiency in New Zealand Friesian and F1 (JerseyNew Zealand Friesian) cows calved during late winter in the $\mathrm{X}^{\text {th }}$ Region, Chile. Arch Med Vet 37, 37-47.

Hazard S. 2004. Alimentación de vacas lecheras. Boletín INIA N ${ }^{\circ} 112$, Pp 52-60.

Hazel LN. 1943. The genetic basis for constructing selection indexes. Genetics 28, 476-490.

Lembeye F, G Castellaro, JC Magofke, H Uribe. 2014. Comparación de distintos índices y criterios de selección en ovinos Merino Precoz manejados en condiciones extensivas de la zona central de Chile. Arch Med Vet 46, 389-397.

Lerdón J, C Muñoz, V Moreira. 2010. Productive and economic characterization of medium and large dairy farmers of southern Chile. IDESIA 28, 41-49.

Livestock Improvement. 2004. Dairy Statistics 2003-2004. Livestock Improvement Corp. Ltd., Hamilton, New Zealand.

López-Villalobos N, D Garrick. 2005. The breeding program for the genetic improvement of New Zealand dairy cattle: an example of a systematic approach to design breeding program. Simposio sobre recursos genéticos y bienestar animal aplicados a la producción animal, Sociedad Chilena de producción animal. SOCHIPA A.G. $11,41-72$.

López-Villalobos N, D Garrick, CW Holmes, HT Blair, RJ Spelman. 2000. Profitabilities of some mating system for dairy herds in New Zealand. J Dairy Sci 83, 144-153.

Misztal I, S Tsuruta, T Strabel, B Auvray, T Druet, D Lee. 2002. BLUPF90 and related program (BGF90). Proceedings $7^{\text {th }}$ World Congress on Genetics Applied to Livestock Production, Montpellier, France, CD-Rom Communication 28, Pp 1-7.

Nelson DL, MM Cox. 2005. Lehninger principios de bioquímica. $4^{\text {th }}$ ed. Omega, Barcelona, España, Pp 343-368.

Parga J, F Lanuza. 2006. Suplementación de vacas lecheras a pastoreo. En: Navarro H, Siebald E, Celis S (eds). Manual de producción de leche para pequeños y medianos productores. Boletín INIA $\mathrm{N}^{\circ} 148$, Pp 57-66.

Prendiville R, KM Pierce, F Buckley. 2009. An evaluation of production efficiencies among lactating Holstein-Friesian, Jersey, and Jersey x Holstein-Friesian cows at pasture. J Dairy Sci 92, 6176-6185.

Sneddon NW. 2011. Review on differences for production, reproduction and environment impact traits between Holstein-Friesian, Jersey and Holstein-Friesian x Jersey crossbred cows. Postgraduate Thesis, Massey University, Palmerston North, New Zealand.

Teuber N. 2009. Praderas permanentes en las zonas lecheras de Chile. Curvas de crecimiento, distribución y producción. Imprenta América, Osorno, Chile.

Welch BL. 1938. The significance of the difference between two means when the population variances are unequal. Biometrika 29, 350-362. 
